\title{
Effect of Zero Tillage and Six Different Genotypes on Growth Attributes of Wheat (Triticum aestivum L.)
}

\author{
Mamta $^{1}$, Mizanul Haque ${ }^{1}$, Kumari Karuna ${ }^{2 *}$, Ashwini Kumar ${ }^{2}$, Manish Kumar ${ }^{3}$, \\ Santosh Kumar Pandit ${ }^{1}$ and Shubham Raj ${ }^{4}$ \\ ${ }^{1}$ Department of Agronomy, ${ }^{2}$ Department of Horticulture (Fruit \& Fruit Tech.), ${ }^{3}$ Department of \\ Entomology, Bihar Agricultural College, Sabour, Bihar, India \\ ${ }^{4}$ Department of Agronomy, J. S. University, Shikohabad, Uttar Pradesh, India \\ *Corresponding author
}

\begin{tabular}{l} 
Ke y w o r d s \\
$\begin{array}{l}\text { Conventional tillage } \\
\text { (CT), Zero tillage } \\
\text { (ZT), Tillers, Leaf } \\
\text { area index (LAI), } \\
\text { Genotypes }\end{array}$ \\
Article Info \\
$\begin{array}{l}\text { Accepted: } \\
10 \text { July } 2020 \\
\text { Available Online: } \\
\text { 10 August } 2020\end{array}$ \\
\hline
\end{tabular}

Keywords

Conventional tillage (CT), Zero tillage (ZT), Tillers, Leaf area index (LAI), Genotypes

\section{Article Info}

Accepted: Available Online. 10 August 2020

\section{A B S T R A C T}

Cereals are generally regarded as the "staff of life". Wheat, rice and maize are the major cereals constituting the staple diet of the majority of the world population among which wheat is counted among the 'big three' cereal crops. Zero tillage enables farmers to sow wheat in left optimum moisture with good germination capacity and increases soil aggregates due to minimal disturbance of soil structure/texture. The present experiment was conducted during rabi season of 2016-17 at agronomy farm of BAU, Sabour, Bihar. Plant height was found to be non-significant with conventional and zero tillage practice while significant with genotypes. With increasing days, the plant height was maximum at maturity stage, the highest recorded value was found in BRW $3708(105.00 \mathrm{~cm})$. Results revealed that better photosynthesis due to greater leaf area index resulted significantly higher dry matter production with more number of tillers per plant was observed in BRW 3708 (LAI-3.85, dry matter accumulation-1057.4 g/m ${ }^{2}$ and tillers - 276.6 tillers $/ \mathrm{m}^{2}$ ) genotype of the wheat. After zero tillage deep tillage remained better over minimum and conventional tillage. Hence, it may be concluded that zero tillage could be useful, cost-effective and environmental friendly approach in order to enhance the wheat yield as compared to other techniques.

\section{Introduction}

Wheat (Triticum aestivum L.) belongs to family Poaceae and is the second most important cereal crop after rice around the globe. It was originated from the area of near East and Ethiopian highlands, but today it is cultivated throughout the world. It is grown under irrigated conditions having water requirements 20-21 inches per acre. Wheat is a tall, annual plant with a height ranging from two to six feet in early varieties. The plant is made up of leaves surrounding a slender stalk that terminates in spikes, or ears, of grain at 
the top of wheat. Each spike, ear, of grain is made up of spikelets, which encloses the wheat grain in between the lemma and the palea. The wheat grain is in the shape of an oval and is what gives wheat its nutritional value. The grain may also vary in its length of brush hairs, either long or short. Cultivated wheat is most commonly grown with physical characteristics of fusiform spikes, are awned (bearded) and are easily threshed.

Holistic management of arable soil is the key to dealing with the most complex, dynamic, and interrelated soil properties, thereby maintaining sustainable agricultural production systems, the lone foundation of human civilization. Any management practice imposed on soil for altering the heterogenous body may result in generous or harmful outcomes. The strategies that developing countries adopt to meet future demand for wheat will depend a great deal on how they are affected by the changes that are sweeping the world economy and transforming the way we conduct research. On the other hand, farmers with less time for field preparation and management after harvesting of kharif crops. Zero tillage has emerged as a better strategy and solution for the farmer to run on time for wheat cultivation.

Around $20 \%$ of the total operational energy required is consumed for tillage which is done for sowing any crop. Conventional tillage practices followed by farmers for raising cultivation wheat after puddle rice need extensive use of machines, labour, waste of time and energy as large number of tractor operations are performed to change the low permeability soil structure created for rice to well aerated structure for wheat. It has also been estimated that on an average $30-35 \%$ of total expenditure of crop production is incurred on tillage and sowing operations. To mitigate these negative effects, resource conservation technologies (RCTs) likes zero tillage, bed planting and laser land levelling saved substantial quantity of irrigation water, reducing the cost of cultivation in terms of land preparation, timely sowing, decreased seed rate, improved water and nutrient-use efficiency, and left indirect effect on mitigating the adverse effect of climate changes (Jat et al., 2014). In general 6-12 tractor operations are performed for growing wheat in different part of the Indo-Gangatic plains depending upon the soil types.

Zero tillage is an extreme form of minimum tillage in which primary tillage is completely avoided and secondary tillage is restricted to seedbed preparation in the row zone only. It is the direct sowing of seed in the field without any disturbance to the soil. Zero tillage planting is a resource- conserving approach, and it helps to control obnoxious weeds, less fuel consumption, better soil structure, texture, shortened field time during tillage operation, increased soil water availability and increased number of Bio-pores, that may facilitate good root growth. Several environmental factors influence wheat yield and its quality, such as temperature, precipitation and its distribution during the growing season, sowing time, soil type, and nitrogen fertilization (Peterson et al., 1992; Anderson et al., 1998; Smith and Gooding, 1999). Some genotypes are characterized by a stable performance, while others vary considerably with the environment (Mariani et al., 1995; Peterson et al., 1998; Ames et al., 1999).

\section{Materials and Methods}

\section{Site of the experiment plot}

Bihar Agricultural College, Sabour is situated between $25^{\circ} 15^{\prime} 40^{\prime \prime}$ North longitude $87^{\circ} 2^{\prime} 55^{\prime}$ " East Latitude with an elevation of 45.72 meters above the mean sea level in the heart of the vast alluvial Gangetic plains of North 
India, South of River Ganga. The climate of the region is semi-arid, subtropical with hot desiccating summer, cold but frost less winter with an average annual rainfall of about 1150 $\mathrm{mm}$ precipitating mainly in between middle of June to middle of October.

\section{Experimental details}

The experimental study was laid out in split plot design and replicated 3 times. Main plot having two treatments i.e. conventional tillage (CT) and zero tillage (ZT) options and Subplots having six treatments i.e. six different wheat genotypes.

\section{Genotypes of wheat used for experiment}

The cultivation of all these wheat variety in North Eastern Plain Zone (NEPZ) is mainly recommended for eastern UP, Bihar, Jharkhand and West Bengal, under timely sown-irrigated and high fertility conditions. The optimum sowing time of these variety is second-third week of November and these respond well up to $150 \mathrm{~kg} \mathrm{~N} / \mathrm{ha}$. The varieties are as follows: BRW $3708\left(\mathrm{~V}_{1}\right)$, CBW 38 $\left(\mathrm{V}_{2}\right)$, DBW $39\left(\mathrm{~V}_{3}\right)$, HD $2967\left(\mathrm{~V}_{4}\right)$, HD 2733 $\left(\mathrm{V}_{5}\right)$ and $\mathrm{K} 0307\left(\mathrm{~V}_{6}\right)$.

\section{Preparation of experimental plot}

The experimental plot was prepared by cross harrowing of the land followed by cross ploughing with cultivator. Each ploughing was followed by planking in order to pulverize the soil, weeds, root stubbles and other crop residues were removed and the levelling of land is an essential component of land preparation, as it ensure uniform availability of water to the plants, and avoid stagnation of water and fertilizers to the crop in the field.

After thorough preparation of the land, the experiment was statistically laid out in the field adopting split plot design with six treatments replicated three times. Each treatment was allocated to individual plot in judicial manners.

\section{Plant height}

Plant height was recorded from three selected culms out of the five plants tagged previously in each plot. The average heights of plants were recorded and calculated for use in statistical analysis.

\section{Number of tillers per meter square}

Total number of tillers per meter row length was recorded at 30, 60, 90 DAS and maturity stage from two sites in each plot and expressed as average number of total tillers per meter square.

\section{Leaf Area Index (LAI)}

The leaf area index was worked out from the uprooted samples plant for dry matter studies. Plants were uprooted in $25 \mathrm{~cm}$. row length. All the leaf were detached from the wheat stem. Out of those leaves, 10 leaves were taken randomly to from a representative sample of the detached leaves. Prints of these were made on paper from which leaf area was calculated with help of planimeter. Then, these ten sample leaves were dried in an oven at $60^{\circ} \mathrm{C}$ till constant weight was reached. With the help of leaf area and the dry matter values a factor was worked out to calculate leaf area per unit of leaf dry matter. Then, all detached wheat leaves from the samples plant dried in the oven. The dry matter of leaves thus obtained formed the basis of working out total leaf area of all the detached leaves from the marked row length (i.e. $25 \mathrm{~cm}$ long row length). Then, leaf area index was calculated by the following formula.

Leaf Area Index $=($ Leaf Area $/$ Ground Area $)$ $\times 100$. 


\section{Dry matter accumulation}

Plants were uprooted in $25 \mathrm{~cm}$. row length at 30, 60 and 90 days and at maturity. Samples were sun dried and finally were dried in an oven at $60^{\circ} \mathrm{C}$ till constant weight was reached for measurement of dry matter and preserved it for further necessary analysis.

The number of days taken from sowing to maturity was recorded as it denotes to the accumulation of dry matter $\left(\mathrm{g} / \mathrm{m}^{2}\right)$ at 30,60 , 90 days after sowing and at harvest stage. Complete loss of green colour from the glumes and peduncle was used as criteria for recording days to maturity.

\section{Harvesting and threshing}

The crop was harvested manually on $22^{\text {th }}$ April, 2017, from the net plot area. After sun drying in open air for three days, the total produce was weighed in bundles. Then the threshing was carried out. Produce of all the plots was threshed separately with threshing machine and grain weight was recorded after cleaning.

\section{Statistical analysis}

A split plot design with 12 treatments and three replications were used for this experimental study. Data were subjected to analysis of variance. The results were interpreted on the basis of ' $F$ ' test (Fisher, 1935) and critical difference (CD) between treatments mean. Interaction effects were discussed only wherever they were found applicable i.e., significant.

Significance among mean was analysed using analysis of variance at $\mathrm{p}>0.05$. The experimental data for different characters were subjected to statistical analysis by adopting the methods appropriate to the design (Cochran and Cox, 1963).

\section{Result and Discussion}

\section{Plant height (cm)}

Mean data on plant height of wheat at different stage of growth as influenced by different tillage practices and wheat genotypes have been presented in table 1 . Analyzed data revealed that plant height of wheat at different growth stage was not significantly influenced by different tillage practices, where as the plant height at different growth stage was significantly influenced by wheat genotypes. The maximum plant height of $22.2 \mathrm{~cm}$ was recorded from the wheat genotypes BRW 3708 which was significantly at par with the plant height recorded from CBW $38(20.8 \mathrm{~cm})$ \& DBW $39 \quad(21.4 \mathrm{~cm})$ \& intern were significantly superior to the plant height recorded from the rest of the wheat genotypes. At 60 DAS the wheat genotype BRW 3708 recorded maximum plant height of $60.5 \mathrm{~cm}$ which was statistically at par with the plant height recorded from the wheat genotypes CBW 38 (58.6cm), DBW 39 $(57.7 \mathrm{~cm})$, HD $2967(57.8 \mathrm{~cm})$ and HD 2733 $(57.3 \mathrm{~cm})$ and intern were significantly superior to the plant height of wheat genotype $\mathrm{K} 0307$ (53.6cm). At $90 \mathrm{DAS}$, the wheat genotypes BRW $3708(100.9 \mathrm{~cm})$ being at par with the plant height of heat genotype CBW $38(95.3 \mathrm{~cm})$ recorded maximum plant height and were significantly superior to the plant height recorded from the rest of the wheat genotypes.

At maturity wheat genotypes BRW3708 attained maximum plant height of $105.0 \mathrm{~cm}$, which intern was statistically at with the plant height recorded from the what genotypes CBW $38(102.9 \mathrm{~cm})$, DBW $39(100.8 \mathrm{~cm})$, HD $2967(100.5 \mathrm{~cm})$, HD $2733(57.3 \mathrm{~cm})$. The lowest plant height was recorded from the wheat genotypes K $0307(94.7 \mathrm{~cm})$. Sharma et al., (2010) reported that plants height of 
wheat were higher under conventional tillage $(72.7 \mathrm{~cm})$ than minimum tillage $(71.1 \mathrm{~cm})$; this was mainly due to increase in size of the spike in wheat crop upto the maturity stage. Singh et al., (2009) also found that plant height of wheat under conventional tillage was higher than that of zero tillage due to heavy competition between crop and weeds. Plant height is the genetic character of the variety.

\section{Number of tillers $/ \mathrm{m}^{2}$}

With referring to the data on number of tillers $/ \mathrm{m}^{2}$ of wheat as influenced by different tillage options and wheat genotypes have been given in table 2 . Analyzed data revealed that the number of tillers $/ \mathrm{m}^{2}$ of wheat at different growth stages were recorded from Conventional and Zero tillage practices were significantly at par, whereas number of tillers $/ \mathrm{m}^{2}$ of wheat genotypes at different growth stages were significantly influenced by different wheat genotypes. At 30 DAS, maximum number of tillers was recorded from the wheat genotypes BRW 3708(70.2) which were significantly superior to the rest of the wheat genotypes. At 60 DAS, the wheat genotypes BRW 3708 (100.0) produced significantly superior to the rest of the genotypes. At 90 DAS, the wheat genotypes BRW 3708 produced significantly more number of tillers/ $\mathrm{m}^{2}$ (285) \& was significantly superior to the number of tillers $/ \mathrm{m}^{2}$ recorded from the different genotypes. Likewise at maturity, more number of tillers were recorded from wheat genotypes BRW 3708 (276.6) \& was significantly superior to the number of tillers $/ \mathrm{m}^{2}$ of wheat genotypes recorded from the rest of the wheat genotypes.

The number of tillers $/ \mathrm{m}^{2}$ of wheat at different growth stages under Conventional and Zero tillage practices were significantly at par signifies the beneficial effects of zero tillage due to development of congenial microclimate for better utilization of plant nutrients available in the soil and less competition faced with weeds. So far wheat genotypes is concerned the number of tillers $/ \mathrm{m}^{2}$ of wheat genotypes at different growth stages were increased significantly across different tillage practices. This might be probably due to genetic potentiality of genotypes in utilizing the various inputs like nutrients, moisture and solar radiation in differentially efficient manner. Increase in nutrient availability resulted in higher nitrogen supply which increased further the tillers number were also reported by Evans, 1975. The growth of buds and tillers are promoted by the phyto-hormone cytokinins which are purine or pyrimidine derivative, both of which are $\mathrm{N}$ containing ring structures and are synthesized from amino acids (Bruinsma, 1979).

\section{Leaf Area Index (LAI)}

Mean data on leaf area index of wheat at different stage of growth as influenced by different tillage practices and wheat genotypes have been presented in table 3 .

In the present investigation data revealed that leaf area index of wheat at different growth stage was not significantly influenced by different tillage practices, where as the leaf area index at different growth stage was significantly influenced by wheat genotypes. At 30 DAS, the maximum LAI (0.90) was recorded from the wheat genotypes BRW 3708 , which was significantly superior to the LAI recorded from the rest of the wheat genotypes. Similarly, at 60 DAS (2.58) \& 90 DAS (3.85) the maximum LAI was recorded from the wheat genotypes BRW 3708 and was significantly superior to the LAI recorded rest of the wheat genotypes.

There is no significant difference in leaf area index under zero and conventional tillage 
might be due better leaf growth rate by high rate of net photo synthesis and sufficient cell expansion under zero tillage condition. The higher LAI might be due to higher number of tillers putting forth more leaves resulting in higher leaf area index. These findings go in line with the work of Pal et al., (2012).

\section{Dry matter accumulation $\left(\mathrm{g} / \mathrm{m}^{2}\right)$}

Mean data on dry matter accumulation of wheat at different stage of growth as influenced by different tillage practices and wheat genotypes have been presented in table 4. Analyzed data revealed that dry matter accumulation of wheat at different growth stages were not significantly influenced by different tillage options, where as different wheat genotypes differ significantly in dry matter accumulation recorded at different growth stages. At $30 \mathrm{DAS}$, the maximum dry matter accumulation $\left(31.2 \mathrm{~g} / \mathrm{m}^{2}\right)$ was recorded from the wheat genotypes BRW 3708, which was significantly superior to the dry matter accumulation recorded from the rest of the wheat genotypes. Similarly at 60 DAS the maximum dry matter accumulation was recorded from the wheat genotypes BRW $3708\left(392.9 \mathrm{~g} / \mathrm{m}^{2}\right)$ and was significantly superior to the dry matter accumulation recorded rest of the wheat genotypes. At 90 DAS, the wheat genotype BRW 3708 produce maximum dry matter $\left(682.5 \mathrm{~g} / \mathrm{m}^{2}\right)$ which was statistically at par with the dry matter recorded from genotype CBW38 $\left(670.4 \mathrm{~g} / \mathrm{m}^{2}\right)$ which intern significantly superior to the rest of the recorded wheat genotypes. At maturity stage, the maximum dry matter accumulation was recorded from the wheat genotypes BRW3708 (1057.4 g/m $\left.{ }^{2}\right)$ and was significantly superior to the dry matter accumulation recorded from the rest of wheat genotypes.

The dry matter production $\left(\mathrm{g} / \mathrm{m}^{2}\right)$ increased as the growth progressed and the maximum value was observed at harvest. Tillage options had non-significant influence on dry matter accumulation of wheat at all the growth stages, whereas dry matter accumulation differed significantly among different wheat genotypes. Bhardwaj et al., (2010) also reported significant variation in dry matter accumulation among the different cultivar tested.

\section{Layout details}

\begin{tabular}{|l|l|}
\hline Design & Split plot design \\
\hline Replication & 03 (Three) \\
\hline Treatment (main plot) & 02 \\
\hline Treatments (sub-plot) & 06 \\
\hline Total plot & 03 \\
\hline Plot size (Gross) & $8.0 \mathrm{~m} \mathrm{x} 1.8 \mathrm{~m}$ \\
\hline Net plot size & $7.0 \mathrm{~m} \mathrm{x} \mathrm{1.4m}$ \\
\hline Bund between treatments & $1.0 \mathrm{~m}$ \\
\hline Spacing & $120 \mathrm{~cm}$ apart $\mathrm{R} \mathrm{to} \mathrm{R}$ \\
\hline Fertilizer dose & $150: 60: 40\left(\mathrm{~N}: \mathrm{P}_{2} \mathrm{O}_{5}: \mathrm{K}_{2} \mathrm{O}\right)$ \\
\hline Seed rate & $100 \mathrm{~kg} / \mathrm{ha}$ \\
\hline
\end{tabular}




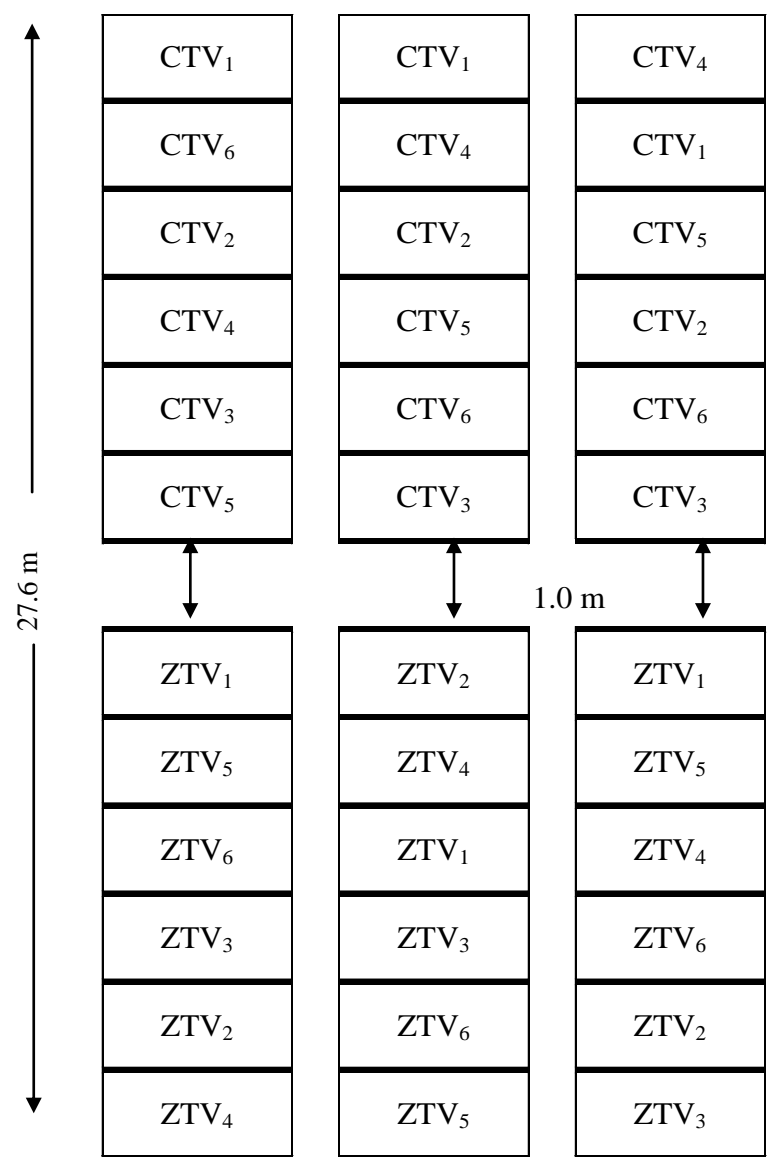

Design: Split-Plot

Replication: Three (03)

Plot Size:

Gross- $1.8 \mathrm{~m} \times 8.0 \mathrm{~m}$

Net- $1.4 \mathrm{~m} \times 7.0 \mathrm{~m}$

Space between Replication; 1.0m

Space between two sub plots-.05m

Treatments:

Main-Plots (Tillage options)

CT-Conventional Tillage

ZT-Zero Tillage

Sub-Plots (Wheat Genotypes)

$\mathrm{V}_{1}$ - BRW 3708

$\mathrm{V}_{2-}$ CBW 38

$\mathrm{V}_{3^{-}}$DBW 39

$\mathrm{V}_{4}-\mathrm{HD} 2967$

$\mathrm{V}_{5^{-}}$HD 2733

$\mathrm{V}_{6}$ K 0307 (V-different variety).

Table.1 Plant height $(\mathrm{cm})$ at different stage of crops as influenced by different tillage options and wheat genotypes

\begin{tabular}{|c|c|c|c|c|}
\hline Treatment & 30 DAS & 60 DAS & 90 DAS & Maturity \\
\hline \multicolumn{5}{|l|}{ Main plot } \\
\hline CT & 20.9 & 57.7 & 93.7 & 102.6 \\
\hline $\mathbf{Z T}$ & 20.7 & 57.4 & 93.5 & 102.4 \\
\hline $\operatorname{SEm}( \pm)$ & 0.5 & 0.9 & 1.2 & 1.3 \\
\hline $\mathrm{CD}(\mathrm{P}=0.05)$ & NS & NS & NS & NS \\
\hline \multicolumn{5}{|l|}{ Sub plot } \\
\hline BRW 3708 & 22.2 & 60.5 & 100.9 & 105.0 \\
\hline CBW 38 & 21.8 & 58.6 & 95.3 & 102.9 \\
\hline DBW 39 & 21.4 & 57.7 & 94.3 & 100.8 \\
\hline HD 2967 & 20.6 & 57.8 & 91.0 & 100.5 \\
\hline HD 2733 & 20.5 & 57.3 & 91.3 & 97.3 \\
\hline K 0307 & 18.1 & 53.6 & 89.0 & 94.7 \\
\hline $\operatorname{SEm}( \pm)$ & 0.61 & 1.34 & 1.9 & 2.0 \\
\hline $\mathrm{CD}(\mathrm{P}=0.05)$ & 1.8 & 3.9 & 5.5 & 5.8 \\
\hline
\end{tabular}

$\mathrm{CT}=$ Conventional tillage $; \mathrm{ZT}=$ Zero tillage 
Table.2 Number of tillers $/ \mathrm{m}^{2}$ at different stage of crops as influenced by different tillage options and wheat genotypes

\begin{tabular}{|c|c|c|c|c|}
\hline Treatment & 30 DAS & 60 DAS & 90 DAS & Maturity \\
\hline \multicolumn{5}{|l|}{ Main plot } \\
\hline CT & 62.5 & 89.2 & 197.2 & 193.0 \\
\hline ZT & 61.2 & 86.6 & 196.7 & 191.8 \\
\hline $\operatorname{SEm}( \pm)$ & 0.93 & 1.5 & 2.9 & 2.3 \\
\hline $\mathrm{CD}(\mathrm{P}=0.05)$ & NS & NS & NS & NS \\
\hline \multicolumn{5}{|l|}{ Sub plot } \\
\hline BRW 3708 & 70.2 & 100.0 & 285.0 & 276.6 \\
\hline CBW 38 & 65.0 & 93.0 & 208.0 & 196.2 \\
\hline DBW 39 & 64.3 & 90.0 & 184.0 & 180.1 \\
\hline HD 2967 & 61.3 & 88.0 & 184.0 & 179.0 \\
\hline HD 2733 & 59.3 & 86.0 & 180.0 & 178.0 \\
\hline K 0307 & 51.0 & 79.0 & 178.0 & 167.5 \\
\hline $\operatorname{SEm}( \pm)$ & 1.47 & 1.97 & 5.15 & 3.3 \\
\hline $\mathrm{CD}(\mathrm{P}=\mathbf{0 . 0 5})$ & 4.3 & 5.8 & 14.3 & 9.7 \\
\hline
\end{tabular}

$\mathrm{CT}=$ Conventional tillage; $\mathrm{ZT}=$ Zero tillage

Table.3 Leaf area index (LAI) at different stage of crops as influenced by different tillage options and wheat genotypes

\begin{tabular}{|c|c|c|c|}
\hline Treatment & 30 DAS & 60 DAS & 90 DAS \\
\hline \multicolumn{4}{|l|}{ Main plot } \\
\hline CT & 0.82 & 2.45 & 3.63 \\
\hline ZT & 0.81 & 2.43 & 3.46 \\
\hline $\operatorname{SEm}( \pm)$ & 0.01 & 0.019 & 0.065 \\
\hline $\mathrm{CD}(\mathrm{P}=0.05)$ & NS & NS & NS \\
\hline \multicolumn{4}{|l|}{ Sub plot } \\
\hline BRW 3708 & 0.90 & 2.58 & 3.85 \\
\hline CBW 38 & 0.84 & 2.50 & 3.82 \\
\hline DBW 39 & 0.84 & 2.49 & 3.80 \\
\hline HD 2967 & 0.81 & 2.48 & 3.47 \\
\hline HD 2733 & 0.80 & 2.44 & 3.30 \\
\hline K 0307 & 0.71 & 2.16 & 3.02 \\
\hline $\operatorname{SEm}( \pm)$ & 0.02 & 0.02 & 0.06 \\
\hline $\mathrm{CD}(\mathrm{P}=0.05)$ & 0.05 & 0.07 & 0.2 \\
\hline
\end{tabular}

$\mathrm{CT}=$ Conventional tillage $; \mathrm{ZT}=$ Zero tillage 
Table.4 Dry matter accumulation $\left(\mathrm{g} / \mathrm{m}^{2}\right)$ at different stage of crops as influenced by different tillage options and wheat genotypes

\begin{tabular}{|c|c|c|c|c|}
\hline Treatment & 30 DAS & 60 DAS & 90 DAS & Maturity \\
\hline \multicolumn{5}{|l|}{ Main plot } \\
\hline CT & 24.3 & 309.7 & 597.4 & 859.0 \\
\hline ZT & 23.1 & 303.6 & 592.2 & 810.6 \\
\hline $\operatorname{SEm}( \pm)$ & 0.57 & 6.4 & 9.8 & 18.4 \\
\hline $\mathrm{CD}(\mathbf{P}=\mathbf{0 . 0 5})$ & NS & NS & NS & NS \\
\hline \multicolumn{5}{|l|}{ Sub plot } \\
\hline BRW 3708 & 31.2 & 392.9 & 682.5 & 1057.4 \\
\hline CBW 38 & 26.5 & 339.4 & 670.4 & 934.9 \\
\hline DBW 39 & 24.2 & 316.1 & 632.2 & 888.6 \\
\hline HD 2967 & 21.4 & 298.9 & 612.9 & 854.3 \\
\hline HD 2733 & 20.8 & 279.8 & 556.1 & 720.5 \\
\hline K 0307 & 18.1 & 212.7 & 415 & 553.1 \\
\hline $\operatorname{SEm}( \pm)$ & 0.82 & 9.3 & 13.4 & 26.0 \\
\hline $\mathrm{CD}(\mathrm{P}=\mathbf{0 . 0 5})$ & 2.4 & 27.4 & 39.4 & 76.8 \\
\hline
\end{tabular}

$\mathrm{CT}=$ Conventional tillage; $\mathrm{ZT}=$ Zero tillage.

Conclusion is as follows:

As discussed above, the following inference could be drawn. Among the different genotypes taken for study in the experiment and zero tillage impact, BRW 3708 recorded the highest value of growth attributes viz. Plant height, number of tillers, LAI and dry matter accumulation which follows the order BRW $3708>$ CBW $38>$ DBW $39>$ HD 2967 $>$ HD 2733 > K 0307.

\section{References}

Ames NP, Clarke JM, Marchylo BA, Dexter JE, Woods SM (1999) Effect of environment and genotype on durum wheat gluten strength and pasta viscoelasticity Cereal Chem. 76: 582-586.

Anderson WK, Shackey BJ, Sawkins D (1998) Grain yield and quality: does there have to be a trade-off? Euphytica 100: 183-188.

Bhardwaj, V., Yadav, V., Chauhan, S. B.
(2010). Effect of nitrogen application timing and varieties on growth and yield of wheat grown on raised beds. Achieves of Agronomy and Soil Science 56(2): 211-222.

Bruisma J (1979). Root Hormones and Overground development, T. K. Scott(ed.), Plant Regulation and World Agriculture. pp . 35-47. Plenum Press, New York.

Cochran WG, Cox GM (1963) Experimental designs. New Delhi, Asia publishershing house. 611.

Evans LT, Wardlaw, Fischer R A (1975) Wheat. In Crop Physiology: Some case Histories (ed. L. T. Evans), pp. 101-49 Cambridge University Press.

Jat RK, Sapkota TB, Singh RG, Jat ML, Kumar M, Gupta RK (2014) Seven years of conservation agriculture in a rice-wheat rotation of Eastern Gangetic Plains of South Asia: Yield trends and economic profitability Field Crop Research 164: 199-210. 
Mariani BM, D’Egidio MG, Novaro P (1995) Durum wheat quality evaluation: influence of genotype and environment Cereal Chem. 72: 194-197.

Pal RK, Murty NS, Rao MMN (2012) Evaluation of Yield, Dry Matter Accumulation and Leaf Area Index in Wheat (Triticum aestivum L.) Genotypes as Affected by Different Sowing Environments Environment \& Ecology 30(4A): 1469-1473.

Peterson CJ, Graybosch RA, Baenziger PS, Grombacher AW (1992) Genotype and environment effects on quality characteristics of hard red winter wheat Crop Sci. 32: 98-103.

Peterson CJ, Graybosch RA, Shelton DR, Baenziger PS (1998) Baking quality of winter wheat: Response of cultivars to environment in the Great Plains Euphytica 100: 157-162.

Sharma AR, Singh R, Dhyani SK, Dube RK (2010) Tillage and legume mulching effects on moisture conservation and productivity of rainfed maize-wheat cropping system Indian Journal of Agronomy 55(4): 245-252.

Singh JP, Hussain SZ, Abrol, Vikas (2009) Impact of tillage and nutrient management in maize- wheat crop rotation under dryland cultivation. Agriculture Mechanization in Asia, Africa and Latin America 40(1): 60-64.

Smith GP, Gooding MJ (1999) Models of grain wheat quality considering climate, cultivar and nitrogen effects. Agric. For. Meteorol, 94: 159-170.

\section{How to cite this article:}

Mamta, Mizanul Haque, Kumari Karuna, Ashwini Kumar, Manish Kumar, Santosh Kumar Pandit and Shubham Raj. 2020. Effect of Zero Tillage and Six Different Genotypes on Growth Attributes of Wheat (Triticum aestivum L.). Int.J.Curr.Microbiol.App.Sci. 9(08): 102-111. doi: https://doi.org/10.20546/ijcmas.2020.908.011 